Review

\title{
Organotypic cultures as tools for optimizing central nervous system cell therapies
}

\author{
Nicolas Daviaud $^{\text {a,b }}$, Elisa Garbayo ${ }^{\text {a,b,c }}$, Paul C. Schiller ${ }^{\text {d,e,f }}$, Miguel Perez-Pinzon ${ }^{\mathrm{g}}$, Claudia N. Montero-Menei ${ }^{\text {a,b,* }}$ \\ a INSERM U1066, 'Micro et Nanomédecines biomimétiques-MINT', Angers, France \\ b LUNAM Université, Université Angers, UMR-S1066, Angers, France \\ c Pharmacy and Pharmaceutical Technology Department, University of Navarra, Pamplona, Spain \\ d Geriatric Research, Education and Clinical Center and Research Services, Bruce W. Carter Veterans Affairs Medical Center, Miami, FL, USA \\ e Department of Orthopedics, University of Miami Miller School of Medicine, Miami, FL, USA \\ ${ }^{\mathrm{f}}$ Department of Biochemistry \& Molecular Biology, University of Miami Miller School of Medicine, Miami, FL, USA \\ g Department of Neurology, University of Miami Miller School of Medicine, Miami, FL, USA
}

\section{A R T I C L E I N F O}

\section{Article history:}

Received 15 February 2013

Revised 15 July 2013

Accepted 18 July 2013

Available online 27 July 2013

\section{Keywords:}

Stem cells

Neurodegenerative disorders

Organotypic slices

Cell behaviour

Cell therapy

Tissue engineering

\begin{abstract}
A B S T R A C T
Stem cell therapy is a promising treatment for neurological disorders such as cerebral ischemia, Parkinson's disease and Huntington's disease. In recent years, many clinical trials with various cell types have been performed often showing mixed results. Major problems with cell therapies are the limited cell availability and engraftment and the reduced integration of grafted cells into the host tissue. Stem cell-based therapies can provide a limitless source of cells but survival and differentiation remain a drawback. An improved understanding of the behaviour of stem cells and their interaction with the host tissue, upon implantation, is needed to maximize the therapeutic potential of stem cells in neurological disorders. Organotypic cultures made from brain slices from specific brain regions that can be kept in culture for several weeks after injecting molecules or cells represent a remarkable tool to address these issues. This model allows the researcher to monitor/assess the behaviour and responses of both the endogenous as well as the implanted cells and their interaction with the microenvironment leading to cell engraftment. Moreover, organotypic cultures could be useful to partially model the pathological state of a disease in the brain and to study graft-host interactions prior to testing such grafts for pre-clinical applications. Finally, they can be used to test the therapeutic potential of stem cells when combined with scaffolds, or other therapeutic enhancers, among other aspects, needed to develop novel successful therapeutic strategies or improve on existing ones.
\end{abstract}

(c) 2013 Published by Elsevier Inc.

\section{Contents}

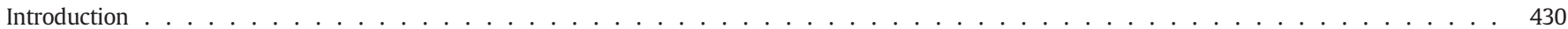

Cell therapy clinical trials for neurological disorders $\ldots \ldots \ldots \ldots$

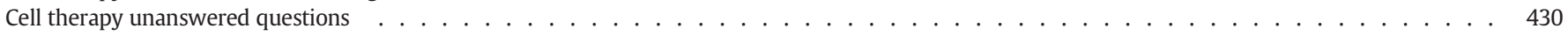

Organotypic slice models as tools for efficient screening of cell behaviour ～. . . . . . . . . . . . . . . . . . . . . . . . . . . 431

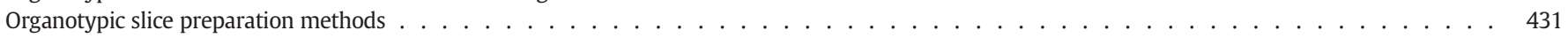

Stem cell transplantation studies using organotypic slices ． . . . . . . . . . . . . . . . . . . . . . . . . . . 4 432

Evaluation of stem cell-based therapies in ex vivo models of neurological disorders . . . . . . . . . . . . . . . . . . . . . . 433

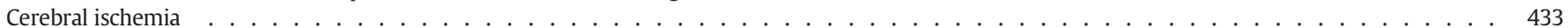

Cerebral ischemia ex vivo models . . . . . . . . . . . . . . . . . . . . . . . . . . . . . . . . . . . . . . . . . . . . . . 4433

Preclinical studies of stem cell therapies using cerebral ischemia organotypic cultures . . . . . . . . . . . . . . . . . . . . . . . . 433

Neurodegenerative disorders: ex vivo models . . . . . . . . . . . . . . . . . . . . . . . . . . . . . . . . 4 434

Parkinson's disease . . . . . . . . . . . . . . . . . . . . . . . . . . . . . . . . . . . . . 434

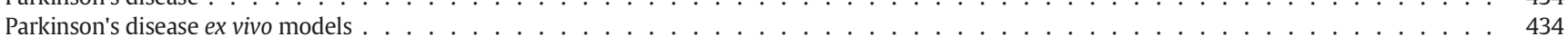

Abbreviations: CI, cerebral ischemia; PD, Parkinson's disease; HD, Huntington's disease; SN, substancia nigra; DA, dopamine; GABA, gamma-aminobutyric acid; MSN, medium spiny neuron; CNS, central nervous system; NSC, neural stem cells; ES, embryonic stem; MSC, mesenchymal stromal cells; iPS cells, induced-pluripotent stem; TH, tyrosine hydroxylase; CA1, Cornu Ammonis layer 1; OGD, oxygen-glucose-deprivation; MPP +, 1-methyl-4-phenylpyridium; 3-NPA, 3-nitropropionic acid; NMDA, N-methyl-D-aspartic acid; NT-3, neurotrophin3; NGF, nerve growth factor; EGF, epidermal growth factor; bFGF, basic fibroblast growth factor; DTG, 1, 3, di-o-tolylguanidine; HUCBC, human umbilical cord blood stem cells; 6-OHDA, 6-hydroxydopamine; QA, quinolinic acid; KA, kainic acid; polyQ, polyglutamine; PAMs, pharmacologically active microcarriers.

* Corresponding author at: INSERM U 1066, IBS-CHU Angers, 4 rue Larrey, 49933 Angers Cx 9, France.

E-mail address: claudia.montero-menei@univ-angers.fr (C.N. Montero-Menei). 
Preclinical studies of stem cell therapies using Parkinson's disease organotypic cultures . . . . . . . . . . . . . . . . . . . 435

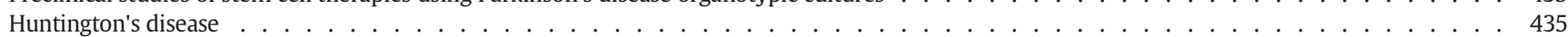

Huntington's disease ex vivo models . . . . . . . . . . . . . . . . . . . . . . . . . . . . . . . . . 436

Studies of stem cells with scaffolds using organotypic cultures ～. . . . . . . . . . . . . . . . . . . . . . . . 436

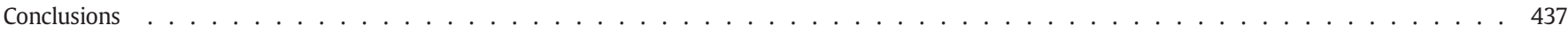

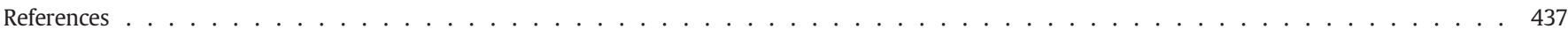

\section{Introduction}

Neurological disorders such as cerebral ischemia (CI), Parkinson's disease (PD), or Huntington's disease (HD) have in common the loss of neurons in the brain. $\mathrm{CI}$ is a condition in which blood flow is curtailed to the brain resulting in neuronal death by oxygen and nutrient deprivation (Barrett and Meschia, 2010). The neurological signs and symptoms of PD are, in large part, a result of selective loss of neurons in the nigro-striatal dopaminergic pathway (for review Lees et al., 2009). In HD gamma-aminobutyric acid (GABA) ergic medium spiny neuron (MSN) death occurs at onset of disease manifestation (for review Walker, 2007). Unfortunately, PD and HD therapies only provide amelioration of symptoms but do not delay or halt neurodegeneration. In $\mathrm{CI}$ if the acute phase is not treated on time, the post-injury neuronal death is the cause of many disabilities. As of today, only thrombolytic therapy has shown any efficacy against $\mathrm{Cl}$. It is therefore essential to evaluate alternative therapeutic strategies such as cell therapy.

Cell therapy for the central nervous system (CNS) consists in cell injection into a lesioned brain tissue to restore a loss of function (Dunnett and Rosser, 2011). However, apart from poor cell engraftment issues that still need to be addressed cell availability and ethical concerns have limited the development and current clinical application of this therapy (Delcroix et al., 2010b; Liu and Huang, 2007). Stem cells that can differentiate into mature neural/neuronal cells can be used as alternative source of cells, as their self-renewal capacity allows the establishment of a cell bank avoiding availability and ethical difficulties. Neurons and glial cells can be generated from neural stem cells (NSC), embryonic stem (ES) cells, bone marrow-derived multipotent stromal cells also called mesenchymal stromal cells (MSC), and also lately, from induced-pluripotent stem (iPS) cells. Each type of stem cell has advantages and caveats that must be taken into consideration together with the type of application envisaged.

Brain organotypic slices, which can be maintained in culture for several weeks, confer a rapid and simple method to evaluate cellular interactions and mechanisms. Moreover, brain slices can be used to develop ex vivo models of neurological disorders and, in this way, they represent a link between in vitro studies and animal models. Cells can be grafted in organotypic slices allowing the researcher to understand how implanted cells interact with resident cellular matrix and injured residential cells and to predict how stem cells may behave in vivo. Thus, they represent a powerful tool to study cell therapy and neuroprotection.

In this review, after a brief overview of the clinical trials performed using cell therapy to treat cerebral disorders and their current limitations, we discuss how organotypic slices could address some of the key unanswered questions regarding cell therapy. We report the different ex vivo models of $\mathrm{CI}, \mathrm{PD}$ and $\mathrm{HD}$ and review the studies carried out using these ex vivo models of neurological disorders to evaluate stem cell therapies. Finally, tissue engineering strategies for PD and other neurological disorders tested in organotypic slices are discussed.

\section{Cell therapy clinical trials for neurological disorders}

Here we will focus on discussing the clinical evaluation of cell-based therapies in which cells are implanted via stereotactic surgery for CI, PD and HD.
The first clinical trials in PD consisted in the striatal stereotactic implantation of adult cells, which may synthesize dopamine (DA) or its precursor, and are thus able to replace the lost DA in the striatum. Over the years, adult cells such as chromaffin cells (for review see Freed et al., 1990), human retinal pigment epithelium cells (for review see Gross et al., 2011; Stover et al., 2005) or carotid body cells (for review see Lopez-Barneo et al., 2009; Minguez-Castellanos et al., 2007) have been evaluated for PD therapy as they lack ethical issues and some of these cell types allow autografts to be performed. Those cell transplantation studies led to a certain improvement of motor functions but cell survival remained too weak limiting their efficacy. Most clinical trials of cell therapy for either PD or for HD consisted of striatal stereotactic implantation of minced foetal tissue or cell suspensions from the ventral mesencephalon or the ganglionic eminence, respectively. They were performed in order to restore lost DA within the striatum for PD patients and lost MSN for HD patients. These trials showed promising results (for review see Barker et al., 2013). However, in PD patients (Mendez et al., 2005), graft induced dyskinesias may occur and Lewy bodies were found in some long survival dopaminergic neurons (for review see Lindvall, 2013; Tomaskovic-Crook and Crook, 2011). But overall, the main limitations concern the poor availability of foetal tissue, the ethical issues associated with their use and the limited survival of the transplanted cells.

Stem cells, which can be isolated from many sources, represent a potential candidate for cell therapy as they self-renew and present a large differentiation potential (for review see Benraiss and Goldman, 2011; Lindvall, 2013). The feasibility of using adult NSCs for PD cell therapy has been demonstrated but their poor availability and an improvement that returns back to baseline after 5 years post-operation suggests that efficacy is limited (Lévesque et al., 2009). Stereotactic implantation of autologous MSCs, which can differentiate into neuronal-like cells and secrete tissue repair and immunoregulatory factors (Tatard et al., 2004), has been evaluated in PD patients (Venkataramana et al., 2010) and in chronic stroke patients for their ability to repair the damaged neuronal tissue (Suarez-Monteagudo et al., 2009). It was concluded that MSCs could safely be grafted into the striatum of patients with good tolerance and no complications. Furthermore, in both cases, a decrease of symptoms associated with the disease was observed.

New clinical trials using adult stem cells are currently on going for the treatment of chronic stroke (NCT01714167 on Clinicaltrials.gov) or for PD (NCT01446614, NCT01453803 on Clinicaltrials.gov). To our knowledge, there are no clinical trials with stem cells for HD.

\section{Cell therapy unanswered questions}

As described above, cells from a variety of sources have shown various degrees of efficacy in clinical trials. However, cell therapy also presents some drawbacks that limit its use, such as poor cell survival and in situ differentiation, certain undesirable side effects and limited availability of foetal tissue. We now discuss the major issues and some future directions of the research associated with cell therapy for neurological disorders.

First of all, findings in a number of experimental models showed that neuronal precursor cell survival within the host tissue after transplantation was too weak (10-20\%) and that cell death occurred within the first 3 weeks (Delcroix et al., 2010b; Liu and Huang, 2007; Olanow et al., 2003). In situ differentiation of stem cells was insufficient (at best 
3-20\%) (Delcroix et al., 2010b; Garbayo et al., 2011a). Moreover, cell survival does not depend only on the type of graft or immunosuppressive treatment but also on the site and method of injection of the cells (Modo et al., 2002). For example, dopaminergic cell suspension grafts implanted into the lesioned striatum presented 20\% higher survival rate of tyrosine hydroxylase ( $\mathrm{TH}$ )-positive neurons (dopaminergic neurons) in comparison to implantation in the intact striatum. Moreover, when a glass capillary was used for implantation, the survival of the single cell suspension was improved by four-fold against the use of a metal cannula (Nikkhah et al., 2009).

Furthermore, many unanswered questions still remain concerning cell therapy for neurological disorders that should be correctly addressed. For instance, which type of cell is more appropriate for a given neurological disorder knowing that they present different properties that fulfil different needs? Therefore, the dose of cells required for successful grafting should be investigated. With this aim in view, the mechanisms of action by which the stem cells survive, differentiate and engraft, should be particularly explored. The adequate cell number and processing must be well established for each disease (Delcroix et al., $2010 \mathrm{~b})$. A better selection of patients and surgical procedure improvement should result in a better outcome for this therapy (Bachoud-Levi et al., 2006; Kondziolka et al., 2000; Lévesque, 2009). The safety of the therapy and the way to manage the potential uncontrolled cell proliferation or tumourigenicity inherent to pluripotent stem cells (ES and iPS cells) must be evaluated. Do stem cells differentiate to undesired cell phenotypes? Do stem cells migrate to non-target sites? Are there functional consequences of these potential scenarios? All of these questions need to be addressed in the appropriate pathological context knowing that cell behaviour will differ depending on the immediate microenvironment. Therefore, cell therapy requires further investigations to increase therapeutic options in the future.

The development and optimization of better experimental models, such as organotypic slices, that allow for better control of the extracellular environment, that allow studying grafted precursors or stem cell responses, cell to cell interactions and the role of the microenvironment on the grafted cell behaviour will be essential to address these issues and further develop cell therapy.

\section{Organotypic slice models as tools for efficient screening of cell behaviour}

In vivo models are indispensable to prove safety, functional outcome and efficacy of a therapy, but in general they require high technical and financial resources, are laborious and time-consuming. Cell transplantation can have parallel effects that are too difficult to observe in vivo as host plastic responses, interference with host neuronal activity and growth factor secretion (Lindvall et al., 2004) and it is impossible to simultaneously test several conditions in the same animal. In vitro models are very quick and simple to develop. Using well-known chemical compounds they can mimic neuronal cell death and neuroprotective therapies can be tested. But those studies can only be performed on a simple cell culture or co-culture which cannot display the complexity of a tissue or an organ and its microenvironment (Zurich and Monnet-Tschudi, 2009).

Since their introduction, organotypic cultures of brain slices have become a useful tool to study physiological and pharmacological properties of tissues. More recently, approaches to lesion the area implied in a pathology were developed to mimic neurodegenerative disorders and in this way, to obtain ex vivo models. Brain slice models offer advantages over other in vitro models because they reproduce the in vivo environment while maintaining key in vitro features. Indeed, these brain slices are relatively inexpensive, easy to prepare and study. There is no need for lengthy animal surgery, or laborious monitoring of multiple physiological parameters, while minimizing ethical issues with the use of animals for experimentation. Furthermore, they maintain the cytoarchitecture and the microenvironment of the original tissue. This 3D environment has tremendous value for evaluating the efficacy of cell therapy, by providing external mechanical inputs, interactions between structures and cell adhesion parameters, which all profoundly affect intracellular signalling. In addition, they enable an easier way to study local cell implantation sites, grafted cell migration and also their interaction with the host environment, mainly glial cells and neurons (Abouelfetouh et al., 2004; Charriere et al., 2010; Jaderstad et al., 2010a, 2010b, 2011; Meng et al., 2011; Sarnowska et al., 2009a; Tanvig et al., 2009; Tonnesen et al., 2011). They are advantageous as they allow patch-clamp studies of neuronal electrophysiology (Finley et al., 2004; Jaderstad et al., 2010b; Kearns et al., 2006; Tonnesen et al., 2011) or studies on the influence of calcium or magnesium on the cells and their correlation with survival or apoptosis markers (Bickler and Fahlman, 2004; Turner et al., 2007).

This model allows for the control of the extracellular media whereby adding biological or pharmacological factors to study their effects represents an advantage over in vivo models (Fig. 1A). Therefore, the effect of growth factors or other chemicals on cell proliferation, cell differentiation or cell survival has been examined using various techniques (del Rio et al., 1991; Nakagami et al., 1997; Pozzo Miller et al., 1994; Su et al., 2011). Moreover, it permits to evaluate the activity of endogenous cells or stem cells and to learn from the environment, for example by the use of "reporter" stem cells, whose behaviour will highlight factors of the microenvironment (Park et al., 2006). Since the microglia remains functional, endogenous immunological interactions can also be assessed (Czapiga and Colton, 1999; Heppner et al., 1998). Furthermore, depending on the region of interest, many slices can be obtained, permitting the use of this ex vivo model for the screening of different therapeutic approaches. Moreover, various techniques may be employed to address basic cellular and molecular mechanisms (Cho et al., 2007) (Table 1). Sorensen et al., have also used organotypic slices from neonates rats as transient storage of dopaminergic donor cells before intracerebral grafting. In this way, pre-grafting examination can be performed as well as pooling and mixing of donor cells which are more mature when they are grafted (Sorensen et al., 1994).

Nevertheless, brain slices remain fragile, they can be easily distorted, and often flatten during the culture. Furthermore, they are more easily generated from young animals, which are more resistant and have stronger neuronal plasticity than adult tissue, which is the age at which the majority of neurological diseases take place. Functional outcome of a therapeutic strategy cannot be evaluated with this technique and generally slice cultures can be only maintained for a few weeks, so long-term assessments are not possible. Organotypic brain slices can only be used to test treatments that will be administrated in the brain by stereotaxy and the impact of the periphery cannot be taken into account. Moreover, the blood brain barrier is not conserved (Table 1).

In summary, even though organotypic cultures have certain limitations, they represent an easy, practical, and efficient way to screen different therapeutic strategies and to address many cellular and molecular mechanisms (Cho et al., 2007; Garbayo et al., 2011a; Sundstrom et al., 2005) prior or in parallel to pre-clinical models.

\section{Organotypic slice preparation methods}

Organotypic culturing was initiated at the end of 1950 with organotypic cultures of chick embryo organs as heart, lung, syrinx (Loffredo Sampaolo, 1956; Meerovitch, 1961) and then in the 60s with fragments of the adult rat hypophysis (Bousquet and Meunier, 1962). Several methods have been developed to maintain brain slices of around $150-400 \mu \mathrm{m}$ in thickness alive in a long-term culture (Fig. 2). The most successful procedure was the "roller tube" technique described in 1981 by Gahwiler et al. (Gahwiler, 1981). In roller-tube cultures, individual slices are placed in flat-sided plastic culture tubes that contain a small amount of culture medium. During the slow rotation the tissue is covered by medium during half of a cycle, resulting in a continuous alternation of feeding and aeration, 

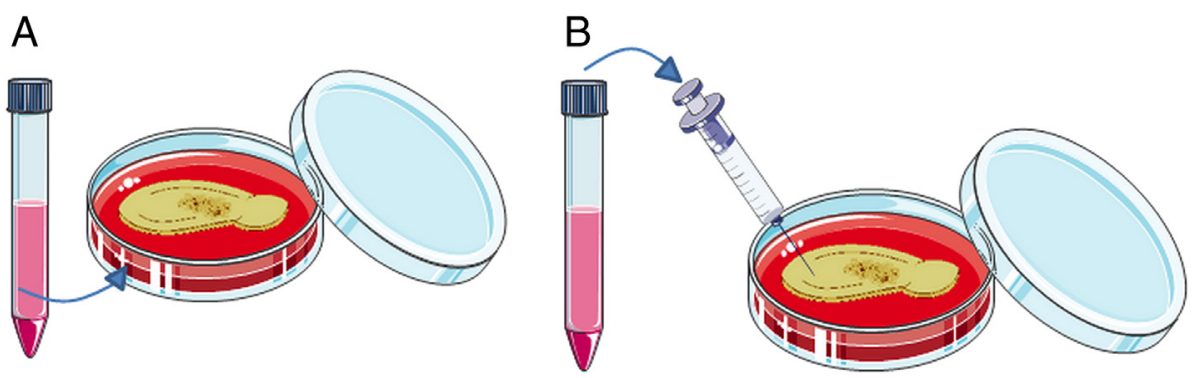

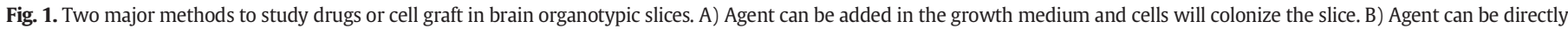
transplanted into the slice using a needle.

which is optimal for slice survival. More recently, in 1991, Stoppini et al. described the membrane interface culture method (Stoppini et al., 1991) that offers easier culture conditions. The tissue is placed directly on semi-porous membranes, and medium is added to the bottom of the culture dish. Slices can collect nutrients contained in the medium on one side and remain optimally aerated from the upper side. This technique is advantageous for studying the effect of a therapeutic agent added onto the organotypic slice, because these slices are never covered with embedding material or media. In general, slices cultured with the roller tube technique get thinner than cultures grown with the interface method due to tissue loss, but they can stay alive a longer time. Depending on the question, one may choose the more efficient technique for slice culturing according to the experiments to be performed. These techniques were further adapted to allow the development of organotypic cultures from different organs and from many hosts such as rats and mice but also rabbits (Savas et al., 2001) pigs (Dall and Zimmer, 2006) and human brain tissue (Jung et al., 2002).

Most organotypic brain slice cultures have been derived from neonatal (P0-P10) animals, but recently also adolescent or adult rats have been used and even human post-mortem brain tissue slices have been kept alive for a few weeks in culture (Finley et al., 2004; Noraberg et al., 2005; Su et al., 2011). The brain area the most cultured in vitro is the hippocampus, now usually prepared using Stoppini's method, with 6-7 day old rats. Over the years slice culture systems have been successfully established from a variety of brain regions including cortex, ventral midbrain, hypothalamus or cerebellum (Gahwiler et al., 1997). Furthermore, co-cultures of different brain slices have been developed, which allow for the assessment of inter-neural responses across brain regions. Nowadays, organotypic slices of many organs have been prepared as for example: liver (Mori et al., 1999), guts (Metzger et al., 2007), retina (Lye et al., 2007), tumour (Froeling et al., 2010) or bladder (Varley and Southgate, 2011) among others.

\section{Stem cell transplantation studies using organotypic slices}

Organotypic slices allow the study of endogenous cell activities. In addition, grafts of cells can also be performed in the slices and, in this way, graft-host interaction and grafted cell behaviour can be analyzed. We will here mainly report stem cell transplantation studies performed with organotypic cultures.

Migration of 5-bromodeoxyuridine-positive grafted cells was tracked and comparison of the migratory capacity of different stem cells showed that human NSCs and rat neurospheres from the subventricular zone seemed to migrate within the slice while MSCs remained at the implantation site (Tanvig et al., 2009). Recently, nanoparticles transporting CoPt, a magnetic product observable by MRI, were used to efficiently tag grafted cells in an organotypic model of spinal cord (Meng et al., 2011). Stem cell engraftment and interaction with the host tissue can also be monitored. It was thus reported that,

Table 1

Advantages and caveats of cell therapy pre-clinical studies performed in organotypic slices.

\begin{tabular}{|c|c|c|c|}
\hline \multirow[t]{2}{*}{ Cell transplantation studies } & \multicolumn{3}{|l|}{ Ex vivo } \\
\hline & References & Advantages & Caveats \\
\hline $\begin{array}{l}\text { 1/Screening of therapeutic } \\
\text { approaches }\end{array}$ & $\begin{array}{l}\text { Sundstrom et al. (2005), Cho et al. (2007), } \\
\text { Sarnowska et al. (2009b) }\end{array}$ & $\begin{array}{l}\text { Six conditions can be tested with one rat } \\
\text { in a few weeks. } \\
\text { Interactions with host tissue easily } \\
\text { explored }\end{array}$ & $\begin{array}{l}\text { Functional outcome of a therapeutic strategy } \\
\text { cannot be evaluated with } \\
\text { this technique }\end{array}$ \\
\hline $2 /$ Grafted cells/host interactions & $\begin{array}{l}\text { Tanvig et al. (2009), Meng et al. (2011) } \\
\text { Abouelfetouh et al. (2004), Sarnowska et al. } \\
\text { (2009b), } \\
\text { Charriere et al. (2010), Jeong et al. (2011) } \\
\text { Jaderstad et al. (2010b, 2011) } \\
\text { Kearns et al. (2006), Jaderstad et al. (2010a), } \\
\text { Tonnesen et al. (2011) }\end{array}$ & $\begin{array}{l}\text { Easy follow-up of tagged cells } \\
\text { Host cells remain functional, including } \\
\text { microglia } \\
\text { Cell functional integration within the host } \\
\text { tissue is easily observed } \\
\text { Patch clamp studies on grafted cells may } \\
\text { be performed }\end{array}$ & $\begin{array}{l}\text { Cannot be conserved more than } 1 \text { month } \\
\text { in culture } \\
\text { Slices can be flattened or distorted } \\
\text { Vascularization and blood brain barrier is not } \\
\text { conserved } \\
\text { Isolated organ/no interaction with } \\
\text { periphery } \\
\text { Slices from young pups/host plasticity differs from } \\
\text { adult }\end{array}$ \\
\hline 3/Neurorepair mechanisms & $\begin{array}{l}\text { Zhong et al. (2003), Park et al. (2006), } \\
\text { Hall et al. (2009), } \\
\text { Horn et al. (2009), Garbayo et al. (2011a, } \\
\text { 2011b) } \\
\text { Jaderstad et al. (2010a) }\end{array}$ & $\begin{array}{l}\text { Ex vivo models of pathologies developed } \\
\text { Host cells remain functional, including } \\
\text { microglia } \\
\text { Allows patch clamp studies }\end{array}$ & $\begin{array}{l}\text { Functional outcome of a therapeutic } \\
\text { strategy cannot be evaluated with this technique } \\
\text { Slices difficult to prepare from adults/they do not } \\
\text { reflect most of the pathological } \\
\text { conditions }\end{array}$ \\
\hline 4/Neuroprotective factors secretion & $\begin{array}{l}\text { Sarnowska et al. (2009a), Garbayo et al. } \\
\text { (2011b) }\end{array}$ & $\begin{array}{l}\text { Culture medium can be collected and } \\
\text { analyzed }\end{array}$ & $\begin{array}{l}\text { Isolated organ/no interaction with } \\
\text { periphery }\end{array}$ \\
\hline $\begin{array}{l}\text { 5/Adjuvant addition of } \\
\text { biomolecules/chemical } \\
\text { compounds }\end{array}$ & $\begin{array}{l}\text { Abouelfetouh et al. (2004), Kearns et al. } \\
\text { (2006), Tonnesen et al. (2011) }\end{array}$ & $\begin{array}{l}\text { Can be added onto the culture medium of } \\
\text { slice } \\
\text { Can be injected directly into the slice }\end{array}$ & Blood brain barrier is not conserved \\
\hline
\end{tabular}




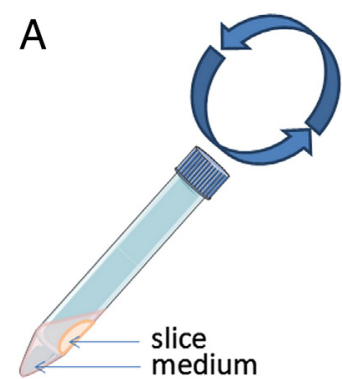

B

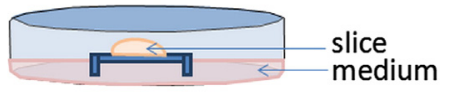

Fig. 2. The two major techniques used to culture brain organotypic slices (Gahwiler et al., 1997). A) Roller tube and B) semiporous membrane. See text for explanation.

human MSCs in contact with human organotypic spinal cord slices differentiate into neuronal cells (Jeong et al., 2011). A small percentage of MSCs are also able to differentiate into neuronal-like cells when deposited directly onto hippocampus slice. Three days post-grafting an increase of the length of the axon-like processes was observed as well as the number of neuronal-positive cells, which increased when retinoic acid was added into the culture medium (Abouelfetouh et al., 2004). In the same way, grafted MSCs could migrate into hippocampal tissue and differentiated into neuronal cells under the microenvironment pressure, but the differentiation rate remained very low (Charriere et al., 2010). As expected, NSC grafts within the striatum integrated morphologically forming part of the 3D cytoarchitecture. Moreover, they increased the overall survival of the organotypic cultures, reduced host cell necrosis and apoptosis while suppressing gliosis (Jaderstad et al., 2010b). Furthermore, connexin expression and early gap junctional intercellular communications were observed between grafted NSCs and host cells, which in this way protected neurons from death (Jaderstad et al., 2010a). It was shown that connexin43 expression and gap junction coupling was essential for neuroprotection (Jaderstad et al., 2011). Interestingly, connexin43 expression of NSC, decreased after transplantation into the host tissue, particularly with NSCs overexpressing neurotrophin-3 (NT-3), while connexin26 expression increased, following the pattern of neuronal differentiation (Jaderstad et al., 2010a, 2011). In a similar manner, bilateral interactions between cord bloodderived human or murine NSCs and the host cells were described. It was found that transplanted neurospheres behave differently depending on the implantation site, may integrate within the host tissue and activate host neuroblasts while inhibiting astrocytosis (Sarnowska et al., 2009b).

Many fundamental studies have been carried out with organotypic brain slices to evaluate endogenous cell or grafted cell behaviour. However, in order to better comprehend the mechanisms underlying proper graft integration in a pathological situation, these studies must be performed in organotypic ex vivo models, which mimic the neurological disorder. These models have been mainly used to study neurorepair and neuroprotection mechanisms in response to different drugs and growth factors, but a few studies have addressed grafted stem cell behaviour.

\section{Evaluation of stem cell-based therapies in ex vivo models of neuro- logical disorders}

As stated above, we here consider neurological disorders for which organotypic cultures have raised particular interest to evaluate stem cell-based therapies. For each neurological disorder, we first describe the ex vivo model and then, we focus on the preclinical studies done in stem cell transplantation using organotypic cultures.

\section{Cerebral ischemia}

Ischemic brain injury occurs due to a cerebrovascular accident leading to a loss of blood supply to part of the brain. The most common type of stroke is characterized by the blockade of arterial vascularization at one site and, as a consequence, a lack of oxygen and glucose that induces cell death and tissue necrosis. Depending on the anatomical site of ischemic insult, $\mathrm{CI}$ can lead to hemiplegia, aphasia or motor dysfunction. $\mathrm{CI}$, is the third cause of death in the US and in Europe with around 200 cases per 100,000 inhabitants per year (Barrett and Meschia, 2010) and almost 6 million victims every year according to the World Health Organization (Lloyd-Jones et al., 2010). Nevertheless, there has been a decrease of stroke mortality of $60 \%$ during the last thirty years due to early patient management. Ischemic stroke treatment begins with medication control aimed at avoiding the aggravation of cerebral injury, and a thrombolytic intravenous administration to dissolve the blood clot; if needed a surgical procedure to unblock vessels may be performed (Tarlov et al., 2012). These patients need to be treated within the first 3-6 $\mathrm{h}$ after stroke to avoid neuronal death; therefore cell therapy can be an attractive delayed treatment to repair damaged tissue, or sustain neuroprotection beyond this treatment window.

\section{Cerebral ischemia ex vivo models}

Several ex vivo approaches are currently used for CI modelling. Among them, hippocampal slices exposed to oxygen and glucose deprivation (OGD) are the most commonly used. This method models global cerebral ischemia, which causes a lack of oxygen and glucose to the brain, leading to the initial degeneration of the neuronal populations of the Cornu Ammonis layer 1 (CA1) in the hippocampus (Cho et al., 2007; Garbayo et al., 2011a; Noraberg et al., 2005; Raval et al., 2003; $\mathrm{Xu}$ et al., 2002). Hippocampal slice cultures are in general made using Stoppini's method. After careful dissection of the hippocampus, 300-400 $\mu \mathrm{m}$ transverse slices can be obtained (Fig. 3A). In those slices, the three main regions of the hippocampus, CA1, CA2 and CA3 are readily observed. Usually, two or three hippocampal slices are placed on a semi-porous membrane and cultured during a maximum of 3-4 weeks with an important conservation of neuronal circuits. The $\mathrm{CI}$ model is obtained by culturing the hippocampal slices in medium without glucose in an anaerobic chamber for $40 \mathrm{~min}$ (Raval et al., 2003; Xu et al., 2002). After that, slices are returned to normoxic conditions and to complete culture media. This OGD treatment induced CA1 hippocampus neuron death, which can reach $80 \%$ in only $24 \mathrm{~h}$. After OGD, endogenous cell response (Bickler and Fahlman, 2004; Ziemka-Nalecz et al., 2013) and neuroprotective effects of different compounds, added into the culture media or directly onto the slice can be assessed (for review see Cho et al., 2007; Noraberg et al., 2005). Another way to produce selective cell death in the CA1 or in the CA3 region is by exposure of the hippocampal slices to Complex I inhibitors, such as rotenone or 1-methyl-4-phenylpyridium (MPP +), to Complex II inhibitors, such as 3-nitropropionic acid (3-NPA), or to excitotoxines, i.e. N-Methyl-D-aspartic acid (NMDA), or to kainic acid (KA) (Noraberg et al., 2005; Xu et al., 2003). These last models based on excitotoxicity only mimic a consequence of energy failure associated with CI. Thus, although they do not completely model CI pathology they correlate well with in vivo observations (Noraberg et al., 2005). On the other hand, OGD closely mimic CI pathology. However, variations in experimental setup can lead to different results and must be taken into account (Table 2).

\section{Preclinical studies of stem cell therapies using cerebral ischemia organotypic cultures}

MSC administration serves as a potential treatment for CI ( $\mathrm{Li}$ et al., 2008). Thus, hippocampal organotypic slices have been used to test MSC effects on CI. It was first shown that a co-culture of OGD slices and MSCs lead to a significant reduction of dead cells in the CA1 area. The protective effect was probably exerted by diffusible factors such as nerve growth factor (NGF) brain derived neurotrophic factor (BDNF) or basic fibroblast growth factor (bFGF) (Zhong et al., 2003). 


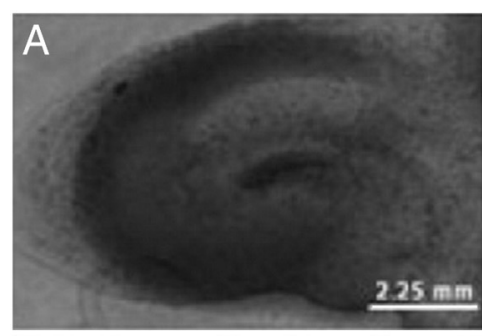

Hippocampal slice

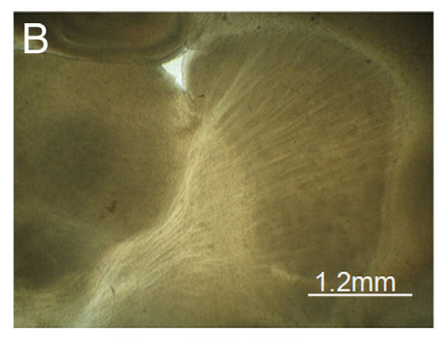

Nigrostriatal slice

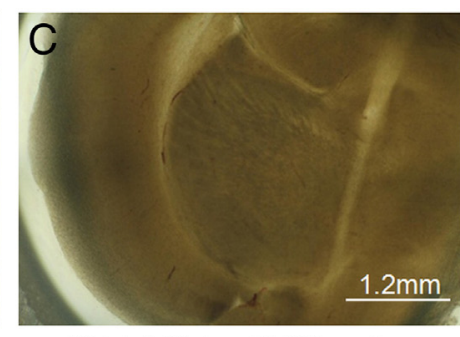

Striatal-Globus Pallidus slice

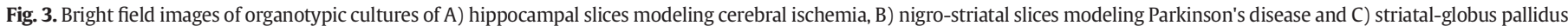
slices modeling Huntington's disease.

More recently, a comparison of MSC and primary cortical cell effects on CI was performed using the OGD model. One day after OGD, the cells were transplanted on the surface of slices. An important decrease of CA1 region cell death was observed, and a concomitant neural differentiation for both types of grafted cells was detected after 7 days (Sarnowska et al., 2009b). Thereafter, OGD slices and cells were co-cultured without direct cell-tissue contact. An important decrease of cell death was also observed with both types of cells, suggesting that they were able to exert neuroprotection by secretion of particularly insulin-like growth factor, bFGF and NGF (Sarnowska et al., 2009a). A homogenous subpopulation of MSC, marrow-isolated adult multilineage inducible (MIAMI) cells, with a broad differentiation potential (D'Ippolito et al., 2006) have shown a reduction of hippocampus OGD induced cell death by, among others, neuroprotective factor secretion (Garbayo et al., 2011b). In another study, human umbilical cord blood stem cells (HUCBC) were compared to sigma receptor agonist 1, 3, di-o-tolylguanidine (DTG), a more classical functional in vivo treatment, in an OGD hippocampal slice. Unlike DTG, HUCBC mediated neuroprotection and limited inflammation by decreasing microglial derived nitric oxide levels detected in normoxic conditions, in the absence of a peripheral immune system (Hall et al., 2009). Nevertheless, in another paradigm an aggravation of the OGD induced lesion in hippocampal slices cultured with MSC conditioned medium was observed, probably involving GABA, NMDA or $\alpha$-amino-3-hydroxy-5-methyl-4-isoxazolepropionic acid receptor agonists (Horn et al., 2009).

\section{Neurodegenerative disorders: ex vivo models}

\section{Parkinson's disease}

PD afflicts $2 \%$ of the population older than 65 years, with 7 to 10 million people affected worldwide. The neurological signs and symptoms of PD are, in large part, a result of selective loss of neurons in the nigrostriatal dopaminergic system. The causes of this neurodegeneration are not fully understood, but it seems that the dopaminergic neuronal death is induced, in part, by the aggregation of $\alpha$-synuclein-containing Lewy bodies (Gazewood et al., 2013; Volles and Lansbury, 2003). The lack of DA causes the classical motor symptoms of bradykinesia, rigidity, resting tremors and loss of postural reflexes. PD is currently treated primarily with various DA replacement pharmacological agents either as monotherapy or in combination with a dopamine decarboxylation inhibitor such as carbidopa or benserazide. This therapy is very effective for the first few years of the illness, but undesirable side effects may appear later (Ecker et al., 2009; Hauser, 2009). Interestingly, neuronal degeneration in this pathology is quite localized at first, so cell therapy has been explored as an alternative approach. In a later stage, cell death related to PD first extends to basal forebrain, transentorhinal cortex, CA2 region of the hippocampus and then to the entire neocortex (Coelho and Ferreira, 2012; Halliday and McCann, 2010).

\section{Parkinson's disease ex vivo models}

The cortico-striatal and mesencephalon-striatal (nigro-striatal) pathways have been extensively studied for PD modelling (Fig. 3B). Organotypic co-cultures of cortex-striatum were first developed and characterized to study the cortico-striatal pathway (Plenz and Aertsen, 1996a; Plenz and Aertsen, 1996b). Further, organotypic rat ventral mesencephalon was co-cultured with striatal, cerebellum or hippocampus slices and an extensive innervation of the striatum by TH-positive fibres from the ventral mesencephalon was observed when co-cultured together (Ostergaard et al., 1990). As PD cell death appears first within the substancia nigra (SN), other groups made organotypic slices of this area to focus on dopaminergic cell bodies (Jaeger et al., 1989). Using this model, Testa et al. studied the molecular mechanism of rotenone (Testa et al., 2005), a pesticide well known to induce nigro-striatal pathway degeneration (Alam and Schmidt, 2002).

To cover the whole nigro-striatal pathway, and so merge many areas involved in $\mathrm{PD}$, a team combined those two techniques to make organotypic cortex-striatum-mesencephalon cultures using the "roller tube" method from Garwhiler (Plenz and Kitai, 1996). For the preparation of these triple slice cultures, cortex, striatum and mesencephalon containing $S N$ coronal sections from post-natal rat brain were gathered and mechanically stabilized on a coverslip by embedding them together with a membrane to reproduce the nigrostriatal pathway. Following attachment to a substrate, the dopaminergic regions of the SN extended processes into the striatum. They proved that cortex-striatum-mesencephalon culture maintained morphological and electrophysiological characteristics of the in vivo preparation (Plenz and Kitai, 1996). But this protocol necessitates performing 3 different slices and merging them onto a single coverslip, so a more skilled operator is required. This triple slice culture model has been used recently to make a comparison of three well-known dopaminergic specific neurotoxins, usually used for in vivo experiments: $\mathrm{MPP}^{+}$(Betarbet et al., 2002), rotenone (Perier et al., 2003), and 6-hydroxydopamine (6-OHDA) (Perese et al., 1989). In this article and in many others, the neurotoxins were directly included in the culture medium (Fig. 1A). In this way, the neurodegeneration is total and homogeneous between the different structures (Kress and Reynolds, 2005). To better mimic the in vivo model, in which the injection of neurotoxins is done stereotactically (Fig. 1B), a group developed organotypic cultures of the ventral mesencephalon with unilateral application of 6-OHDA in either the striatum or SN using a microelectrode to do the injections. In the case of cortical slices, this technique permits to introduce a simple method for generation of an internal control, by treating only one side of the brain, just as in vivo models (Stahl et al., 2009). In this ex vivo model, neurodegeneration is identically obtained as in animal models, so observed degeneration is similar allowing to a certain extent direct comparisons between these two models.

A new organotypic slice technique was developed by vibroslicing rat brain sagittally in order to keep the whole functional architecture and 
Table 2

Development of neurological disorders ex vivo models.

\begin{tabular}{|c|c|c|c|}
\hline & Ex vivo models & Observations/remarks & References \\
\hline \multirow[t]{2}{*}{$\begin{array}{l}\text { Cerebral } \\
\text { ischemia }\end{array}$} & OGD treatment on hippocampal slices & $\begin{array}{l}\text { Easy access and precise control of extracellular environment, } \\
\text { which makes it suitable to study detailed molecular mechanisms } \\
\text { associated with CI }\end{array}$ & $\begin{array}{l}\text { Bickler and Fahlman (2004), Noraberg et al. } \\
\text { (2005), Garbayo et al. (2011b), Ziemka-Nalecz } \\
\text { et al. (2013) }\end{array}$ \\
\hline & $\begin{array}{l}\text { Complex I inhibitors as rotenone or MPP }+ \text {, } \\
\text { Complex II inhibitors as 3-NPA or excitotoxine as } \\
\text { NMDA, Kainic acid }\end{array}$ & $\begin{array}{l}\text { Correlate well with in vivo observations but only mimic a } \\
\text { consequence of energy failure associated with } \mathrm{CI}\end{array}$ & Xu et al. (2003), Noraberg et al. (2005) \\
\hline \multirow[t]{4}{*}{$\begin{array}{l}\text { Parkinson's } \\
\text { disease }\end{array}$} & $\begin{array}{l}\text { Addition of } \mathrm{MPP}^{+}, \text {Rotenone or 6-OHDA on triple } \\
\text { slice culture medium }\end{array}$ & A specific dopaminergic degeneration is obtained & Kress and Reynolds (2005) \\
\hline & $\begin{array}{l}\text { Unilateral application of 6-OHDA in either the } \\
\text { striatum or SN }\end{array}$ & $\begin{array}{l}\text { PD is identically obtained in animal models and allows } \\
\text { generating an internal control }\end{array}$ & Stahl et al. (2009) \\
\hline & Cortex-corpus callosum-striatum-SN slices & $\begin{array}{l}\text { Mechanical denervation of the nigro-striatal pathway by cutting } \\
\text { the medial forebrain bundle } \\
\text { Allow studying all areas/pathways involved in this pathology }\end{array}$ & Cavaliere et al. (2010) \\
\hline & Mouse sagittal slices exposed to 6-OHDA & $\begin{array}{l}\text { Long-term viability with intact cytoarchitecture throughout } \\
\text { cortical and subcortical regions }\end{array}$ & Kearns et al. (2006) \\
\hline \multirow[t]{4}{*}{$\begin{array}{l}\text { Huntington's } \\
\text { disease }\end{array}$} & $\begin{array}{l}\text { Kainic acid, quinolinic acid or 3-nitropropionic } \\
\text { acid addition }\end{array}$ & $\begin{array}{l}\text { Easy and rapid to develop and neurodegeneration similar to the } \\
\text { one observed in HD but do not take account the genetic } \\
\text { component of the pathology }\end{array}$ & $\begin{array}{l}\text { Matyja (1986), Whetsell and Schwarcz (1989), } \\
\text { Beal et al. (1991), Storgaard et al. (2000), Colle } \\
\text { et al. (2012) }\end{array}$ \\
\hline & $\begin{array}{l}\text { Hippocampal slices established from the R6/2 } \\
\text { transgenic mice }\end{array}$ & $\begin{array}{l}\text { Provide a model to assess inhibitors of huntingtin aggregation in } \\
\text { a system close to in vivo models }\end{array}$ & $\begin{array}{l}\text { Jana et al. (2000), Smith et al. (2001), Smith } \\
\text { and Bates (2004), Hay et al. (2004) }\end{array}$ \\
\hline & Transfection with a mutant huntingtin gene & $\begin{array}{l}\text { Mutant gene can be the same one used for } \mathrm{R} 6 / 2 \text { mice model } \\
\text { Human mutant huntingtin can be used }\end{array}$ & $\begin{array}{l}\text { Murphy and Messer (2001), Reinhart et al. } \\
\text { (2011) }\end{array}$ \\
\hline & & Merges all features of human HD cellular pathology & \\
\hline
\end{tabular}

pathways of the brain (Ullrich et al., 2011). This organotypic slice allows performing investigations on those pathways and also interactions with glial cells and capillaries, but no dopaminergic neurodegeneration of the nigro-striatal pathway is observed. In the same way, sagittal vibrosections of mouse brain were performed. Sagittal slices maintained neuronal pathway integrity during three weeks in culture and were immersed into 6-OHDA to induce a dopaminergic pathway degeneration (Kearns et al., 2006). Based on those studies, our team has begun the development of an ex vivo PD model in which a mechanical degradation of the nigro-striatal pathway is obtained. Sagittal slices are performed with an angle of $14^{\circ}$ which induce the degeneration of the medial forebrain bundle which dispenses neurotoxin use (Daviaud et al., 2011).

Another organotypic model of nigro-striatal degeneration was developed by another group to study PD hallmarks. Two-or threeday old rat brains were separated in two hemispheres and the cerebellum was removed. The resulting brain blocks were cut dorso/ventrally with a vibratome using a $45^{\circ}$ inclination. Slices containing cortex-corpus callosum-striatum-SN were selected. The PD model was obtained by a mechanical denervation of the nigrostriatal pathway, by cutting the medial forebrain bundle near the SN, thus leading to retrograde and anterograde neuronal degeneration in the SN and in the striatum, respectively. They compared mechanical lesion degeneration with 6-OHDA treatment of the whole slice. They showed that denervation induced a loss of about $60 \%$ of $\mathrm{TH}$ expression in the striatum and the SN in 3 days when this loss is about $30 \%$ in the same slices treated with 6-OHDA. The mechanical lesion model is an interesting tool to study mechanisms of neurodegeneration, as well as neuroregeneration without use of neurotoxins but it also damaged glutamatergic pathway and the GABAergic projections, while the 6-OHDA injection model is more specific for dopaminergic pathway (Cavaliere et al., 2010). In this way, scientists can either choose a dopaminergic specific model, which is closer to the in vivo model and mimics early PD, or a dopaminergic/glutamatergic/GABAergic degeneration, which is closer to an advanced PD model. Those two last models seem to be the more complete, simple and appropriate to study PD. Indeed, they allow studying all areas involved in this pathology and conserve many pathways that interact with this major neurodegeneration pathway. Furthermore they are based on unique slice culture, which is simpler to develop than co-cultures (Table 2).

One of the main advantages of these ex vivo PD models is that they provide a therapeutic screening platform without the need of time- consuming whole animal studies. However, the major drawback is that functional effects cannot be analyzed.

\section{Preclinical studies of stem cell therapies using Parkinson's disease organotypic cultures}

A few studies have used striatal organotypic cultures to monitor the interaction of grafted NSCs and the host striatal cells, but those slices did not present a nigro-striatal dopaminergic degeneration, which alter the micro-environment and may modify the cell/host interaction. A recent study, transplanted Wnt5a-overexpressing-NSCs, expanded as neurospheres, into PD organotypic cultures from 6-OHDA-treatedmouse striatum (Tonnesen et al., 2011). This study showed that grafted cells integrated the DA-denervated striatum and created bidirectional interactions with the host cells including host striatal presynaptic regulation of host cortical afferents to the grafted DA neurons and polysynaptic graft-to-host connections. Patch clamp studies were performed on grafted cells. An important depolarization of GABA receptor-mediated chloride currents in the DA neurons was observed, which is characteristic of endogenous dopaminergic neurons, but may also indicate partial immaturity. To confirm the importance of those results, similar experiments were performed in 6-OHDA-lesioned animals. In vivo grafted cells had similar morphological and electrophysiological properties than ex vivo grafted cells showing their maturity and integration in the organotypic slice.

Mouse embryonic stem cell derived neural precursor cells were implanted into a mouse sagittal slice previously treated with 6-OHDA. Viable cells were observed up to three weeks in culture and showed a dopaminergic differentiation when many factors as bFGF, sonic hedgehog or pleiotrophin were added in the culture media. Furthermore, patch clamp studies allowed recording action potentials, as well as postsynaptic currents, into grafted cells, localized by their capacity to express GFP, demonstrating functional integration and maturation within the host tissue (Kearns et al., 2006).

\section{Huntington's disease}

$\mathrm{HD}$ is an autosomal dominant genetic neurodegenerative disorder with a prevalence of 6 to 7 for 100,000 around the world (Walker, 2007). This pathology results in abnormal involuntary movements (chorea and dystonia), cognitive decline, behavioural changes and a range of psychiatric disorders, especially depression. These symptoms, 
which gradually develop, are caused on an earlier stage by degeneration of the striatal neurons, especially of GABAergic striatal MSNs which project to the external segment of the globus pallidus, the SN pars compacta and pars reticulata. Then, the gradual neuronal loss extends throughout the brain (Ho et al., 2001). The huntingtin gene is localized on chromosome 4 and the normal allele on this site contains a trinucleotide repeat sequence (CAG) encoding polyglutamine, but this CAG repeat is amplified in patients suffering from HD. When the repetition reaches 39 or more, the pathology will develop generally at around 30-40 years. Although CAG repeats greater than 55 are associated with early age of onset (juvenile HD) and more rapid progression, there is no correlation between age of onset and number of repeats ranging from 40 to 50 (for review see Ho et al., 2001; Ha and Fung, 2012). No cure exists for this disease and antichoreic drugs or neuroleptics only reduce the severity of the symptoms. Moreover, their administration can cause side effects such as bradykinesia or depression, and are ineffective in stopping or reversing cell death (Adam and Jankovic, 2008). With HD, the neurodegeneration is mainly localized in the striatum at onset of the pathology, so cell therapy represents an attractive alternative treatment. Unfortunately, for advanced cases, HD is less optimal for cell therapy because the entire brain becomes involved (Wijeyekoon and Barker, 2011).

\section{Huntington's disease ex vivo models}

The first HD organotypic model developed dates back to 1986 with the study of the effects of KA administration on glial cells, both in the animal model of HD (which uses this drug to damage GABAergic neurons) and in striatal organotypic cultures. Indeed, glial cells have a major role in brain homeostasis and should be thoroughly investigated in neurodegenerative disorder models. This study proved that KA might act directly on astroglia cells by a transformation of the protoplasmic type of astroglia into the fibrous type; changes that were independent of neuronal damage (Matyja, 1986). The effect of quinolinic acid (QA) has also been tested on organotypic cultures of rat caudate nucleus or on combination cultures of frontal cortex and caudate nucleus. Light microscopy analysis proved that QA induced excitotoxic damage on the rat brain which models HD (Whetsell and Schwarcz, 1989). QA induced a loss of markers of spiny neurons (GABA and substance P), an increase in markers of aspiny neurons (somatostatin and neuropeptide $\mathrm{Y}$ ) and a diminution of choline acetyltransferase activity, similar to changes observed in HD (Beal et al., 1991). Striatal degeneration of HD can also be caused in vivo by 3-NPA, a mitochondrial inhibitor. To better understand the neurotoxicity and possible indirect excitotoxicity mechanisms, 3-NPA was added into organotypic striatal and cortico-striatal slice culture medium. In this way, the authors proved that neuronal activity of the glutamatergic cortico-striatal pathway contributed to striatal pathology and that in vivo characteristics of 3-NPA toxicity can be reproduced in organotypic slices (Storgaard et al., 2000). Recently, QA, 3-NPA and the combination of these two toxins were tested to model HD in $400 \mu \mathrm{m}$ striatal slices. The effects of NMDA receptor antagonist MK-801, of succinate and of reactive oxygen species were investigated. It was concluded that each model induces these processes in a differential manner: QA by NMDA receptor activation and 3-NPA by succinate dehydrogenase inhibition. Those effects were blocked by probucol, an antioxidant compound with scavenger properties (Colle et al., 2012). There is an important variety of those models, based on the different neurotoxins used and addition into the culture media or either directly injected onto the slices, leading to a heterogeneity of results obtained, which must be taken in consideration. Furthermore with that type of model, only the cellular aspect of HD can be studied, they can't take into account the genetic component of the pathology. Conversely they are easy and rapid to develop and do not involve high economic impact as normal rodents are used.

A model of organotypic hippocampal slices established from the R6/2 transgenic mice, which presents a CAG repetition, was developed showing the same formation of PolyQ aggregates in all of the hippocampus slice neurons, appearing first in the CA1 followed by the CA2 and later in the CA3 after 5 weeks. Creatine administration can block this aggregation in vivo, and this was confirmed in this organotypic model (Smith et al., 2001). Using this same model it was shown that a maintained overexpression of a chaperone protein HSP70, which is co-localized with nuclear aggregates in HD patients, could delay aggregate formation (Hay et al., 2004; Jana et al., 2000). In another study organotypic hippocampus slice of R6/2 mice is clearly established as a screening model of anti-aggregation components (Smith and Bates, 2004).

Another way to mimic HD is the transfection of HD-polyQ-GFP plasmids into cells within the slice. Three different non-viral transfection methods were tested on mouse cerebellum organotypic slices (Murphy and Messer, 2001). Mouse cortico-striatal slices could then be transfected with a mutant huntingtin gene and when exposed to malonate produced HD-like lesions and provided a new model of HD, conserving the correlation between CAG repetitions and aggregation length. A co-transfection of anti-HD single-chain Fv intrabodies can lead to a reduction of the physiological consequences and a diminution of cells expressing large aggregates after three days of culture (Murphy and Messer, 2004). More recently a new HD model was developed based on the acute transfection of rat cortico-striatal brain slices with DNA constructs derived from the human pathological huntingtin gene. This transfection of mutant huntingtin induced GABAergic MSNs death within 3 days. Furthermore, the transfected mutant gene is the same used for R6/2 mice model. Thereby, the model developed is very close to in vivo models, and merged all features of HD cellular pathology in a very specific manner. A screening of a chemical library of 74 neuroprotective and anti-inflammatory drugs implicated in HD was performed and Chemokine receptor, I $\kappa \beta$ kinase complex and c-Jun N-terminal kinase particularly showed neuroprotective effects (Reinhart et al., 2011).

Those more recent models of HD are very powerful; they properly mimic the pathology including the genetic aspect of HD and as a consequence lead to the MSN death. Two majors techniques can lead to this model, in the first one organotypic slices are made directly on transgenic mice, and in the second organotypic slices are prepared from normal rodents and slices are transfected. The first protocol appears to be easier to develop because R6/2 mice can be purchased, so model acquirement does not demand specific knowledge but may be more expensive in a long term. Inversely, slice transfection involves high technology equipments and a skilled operator but normal rodents can be used, and a better control of the transfected cDNA construct obtained. Despite those very powerful HD ex vivo models, no therapy using stem cells has been studied using HD organotypic cultures.

\section{Studies of stem cells with scaffolds using organotypic cultures}

The development of new tools able to enhance the potential of cell therapy is needed. Tissue engineering is the combination of cells with materials, scaffolds, and biochemical or physico-chemical factors to improve their biological effects. In addition, cells are responsive to the architecture and to mechanical properties of the scaffolds, which can modulate morphology, proliferation and, in the case of stem cells, differentiation. Micro- or nano-capsules, micro- or nano-particles and gels, which can all be polymeric, aqueous, lipidic, are very different tools used to improve potential treatments (Subramanian et al., 2009; Williams and Lavik, 2009). In our laboratory we have developed a cell and drug carrier, named the pharmacologically active microcarriers (PAMs). They are polymeric biodegradable microspheres that offer a 3 dimensional support for cells. Moreover they can present a biomimetic surface of extracellular matrix protein to enhance survival and/or differentiation of grafted cells and lastly they can release a growth factor in a controlled manner during PAM degradation. Those combined parameters increase cell survival, differentiation and integration in the 
host tissue (Bouffi et al., 2010; Delcroix et al., 2011; Tatard et al., 2004, 2005, 2007b).

Tissue engineering is an ongoing area of research that may also use organotypic slices to demonstrate its therapeutic potential (Fig. 4). With this aim and to mimic in vivo conditions, a co-culture of cortex organotypic slices and matrigel was developed. Matrigel is a gelatinous protein mixture, similar in composition to basement membrane with extracellular matrix and proteins, and allows 3D cell culture. The co-culture of matrigel with cortex organotypic slices allowed demonstrating axon elongation from the cortex to the matrigel and the ability of cells implanted into the gel to promote axonal growth. This ex vivo model provided a good means to screen transplanted cells for axon growth and cell-cell communication potential before in vivo experiments (Ishihara et al., 2011). To enhance CNS cell transplantation, gelatin-laminin-cryogels and dextran-laminin-cryogels transporting HUCBC were prepared. Cryogels are a cryogelation of a mixture of protein from the extracellular matrix with either gelatin or dextran. They can carry transplanted cells while offering them physical and stress protections and can promote cell differentiation. Organotypic hippocampal slice cultures were prepared as a 3D screening tool, in which aggregates of scaffold-conveying cells were transplanted into the CA1 region. It was proved that scaffold implantation did not induce inflammation, microglial activation and prevented astrocytic scar formation. Furthermore, laminin scaffolds attracted infiltration of neuroblasts making them an interesting tool for brain circuit regeneration (Jurga et al., 2011).

Neuroprotective properties of MIAMI cells adhered onto PAMs were demonstrated by our group using an ex vivo model of $\mathrm{CI}$ (Garbayo et al., 2011b). MIAMI cells can differentiate into neuronal-like cells (Tatard et al., 2007a) and after epidermal growth factor (EGF) and bFGF pretreatment their response to neuronal commitment is increased (Delcroix et al., 2010a). As many other cells, when combined to scaffolds their regenerative potential may be increased. One hour after OGD of hippocampal slice cultures MIAMI cells, or EGF-bFGF pre-treated MIAMI cells adhered onto PAMs, injected into the CA1 cell body layer of hippocampal slices significantly protected the CA1 region against ischemic death. Cell therapeutic value was significantly increased when delivering the cells complexed with fibronectin-coated microcarriers, by increasing stem cell survival, neuronal differentiation and paracrine secretion of different factors. Those results were then confirmed using an in vivo CI model (Garbayo et al., 2011b). MIAMI cells adhered to PAMs with a laminine biomimetic surface and delivering NT-3, improved survival and differentiation of stem cells and induced a strong functional recovery in an animal model of PD (Delcroix et al., 2011). Based on those results we have developed a new ex vivo PD model (Daviaud et al., 2011) to study the molecular mechanisms of this functional recovery using two different stem cells enabling to compare their mechanisms of action (Daviaud et al., 2011).

\section{Conclusions}

As described here, organotypic cultures of many organs were developed showing the great potential and interest of this model. Obviously, organotypic slices cannot replace in vivo models, which remain the only way to evaluate the functional outcome of a therapeutic strategy. However, organotypic brain slices can model different histopathological aspects of neurological conditions and can be used to address some of the difficulties limiting stem cell therapy approaches. Organotypic culture technique is fast, efficient and practical, allows reduction of animal number and preserves the 3D neuronal network. Many regions of the brain can be cultured alone or co-cultured with other regions. They can serve as screening platforms, to study the effects of drugs, cell grafts alone or combined with biomaterials injected onto the slices.

\section{References}

Abouelfetouh, A., Kondoh, T., Ehara, K., Kohmura, E., 2004. Morphological differentiation of bone marrow stromal cells into neuron-like cells after co-culture with hippocampal slice. Brain Res. 1029, 114-119.
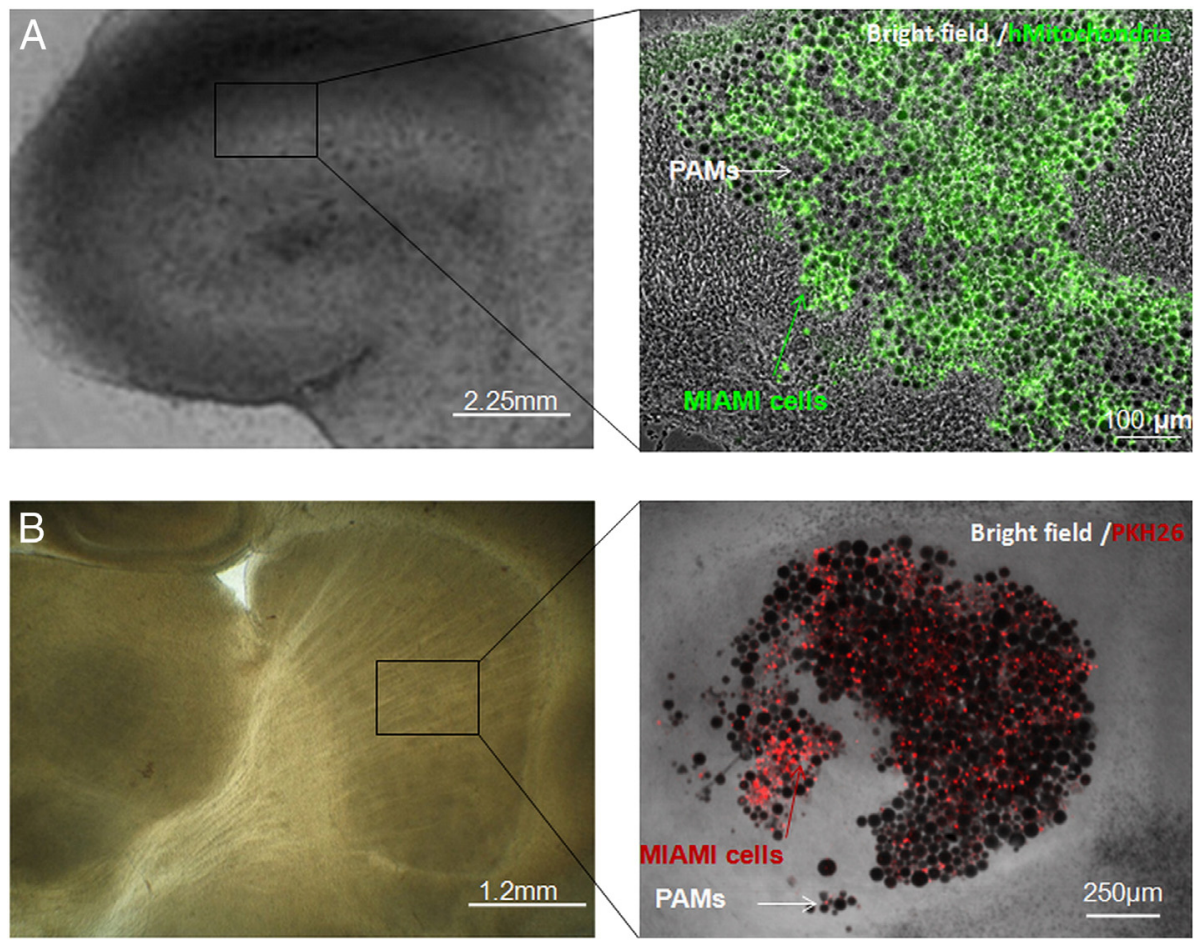

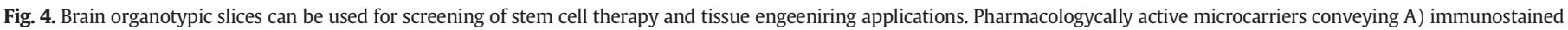
stem cells injected into hippocampal organotypic cultures and B) PKH-26 labelled stem cells injected into nigrostrial organotypic cultures. 
Adam, O.R., Jankovic, J., 2008. Symptomatic treatment of Huntington disease. Neurotherapeutics 5, 181-197.

Alam, M., Schmidt, W.J., 2002. Rotenone destroys dopaminergic neurons and induces parkinsonian symptoms in rats. Behav. Brain Res. 136, 317-324.

Bachoud-Levi, A.C., Gaura, V., Brugieres, P., Lefaucheur, J.P., Boisse, M.F., Maison, P., Baudic, S., Ribeiro, M.J., Bourdet, C., Remy, P., Cesaro, P., Hantraye, P., Peschanski, M., 2006. Effect of fetal neural transplants in patients with Huntington's disease 6 years after surgery: a long-term follow-up study. Lancet Neurol. 5, 303-309.

Barker, R.A., Barrett, J., Mason, S.L., Bjorklund, A., 2013. Fetal dopaminergic transplantation trials and the future of neural grafting in Parkinson's disease. Lancet Neurol. 12, 84-91.

Barrett, K.M., Meschia, J.F., 2010. Acute ischemic stroke management: medical management. Semin. Neurol. 30, 461-468.

Beal, M.F., Ferrante, R.J., Swartz, K.J., Kowall, N.W., 1991. Chronic quinolinic acid lesions in rats closely resemble Huntington's disease. J. Neurosci. 11, 1649-1659.

Benraiss, A., Goldman, S.A., 2011. Cellular therapy and induced neuronal replacement for Huntington's disease. Neurotherapeutics 8, 577-590.

Betarbet, R., Sherer, T.B., Greenamyre, J.T., 2002. Animal models of Parkinson's disease. Bioessays 24, 308-318.

Bickler, P.E., Fahlman, C.S., 2004. Moderate increases in intracellular calcium activate neuroprotective signals in hippocampal neurons. Neuroscience 127, 673-683.

Bouffi, C., Thomas, O., Bony, C., Giteau, A., Venier-Julienne, M.C., Jorgensen, C., MonteroMenei, C., Noel, D., 2010. The role of pharmacologically active microcarriers releasing TGF-beta3 in cartilage formation in vivo by mesenchymal stem cells. Biomaterials 31 , 6485-6493.

Bousquet, J., Meunier, J.M., 1962. Organotypic culture, on natural and artificial media, of fragments of the adult rat hypophysis. C. R. Seances Soc. Biol. Fil. 156, 65-67.

Cavaliere, F., Vicente, E.S., Matute, C., 2010. An organotypic culture model to study nigrostriatal degeneration. J. Neurosci. Methods 188, 205-212.

Charriere, K., Risold, P.Y., Fellmann, D., 2010. In vitro interactions between bone marrow stromal cells and hippocampal slice cultures. C. R. Biol. 333, 582-590.

Cho, S., Wood, A., Bowlby, M.R., 2007. Brain slices as models for neurodegenerative disease and screening platforms to identify novel therapeutics. Curr. Neuropharmacol. 5, 19-33.

Coelho, M., Ferreira, J.J., 2012. Late-stage Parkinson disease. Nat. Rev. Neurol. 8, 435-442.

Colle, D., Hartwig, J.M., Soares, F.A., Farina, M., 2012. Probucol modulates oxidative stress and excitotoxicity in Huntington's disease models in vitro. Brain Res. Bull. 87, 397-405.

Czapiga, M., Colton, C.A., 1999. Function of microglia in organotypic slice cultures. J. Neurosci. Res. 56, 644-651.

Dall, A.M., Zimmer, J., 2006. Development of DARPP-32-positive parts of fetal pig ganglionic eminence and ventral mesencephalon in organotypic slice co-cultures. Exp. Neurol. 200, 250-255.

Daviaud, N., Garbayo, E., Sindji, L., Serrano, A.M., Perez-Pinzon, M., Schiller, P.C., MonteroMenei, C.N., 2011. Pharmacologically Active Microcarriers Carrying Stem Cells for Tissue Engineering in an Organotypic Model of Neurodegenerative Disorders. Tissue Engineering \& Regenerative Medicine International Society (TERMIS) (December).

Del Rio, J.A., Heimrich, B., Soriano, E., Schwegler, H., Frotscher, M., 1991. Proliferation and differentiation of glial fibrillary acidic protein-immunoreactive glial cells in organotypic slice cultures of rat hippocampus. Neuroscience 43, 335-347.

Delcroix, G.J., Curtis, K.M., Schiller, P.C., Montero-Menei, C.N., 2010a. EGF and bFGF pretreatment enhances neural specification and the response to neuronal commitment of MIAMI cells. Differentiation 80, 213-227.

Delcroix, G.J., Schiller, P.C., Benoit, J.P., Montero-Menei, C.N., 2010b. Adult cell therapy for brain neuronal damages and the role of tissue engineering. Biomaterials 31, 2105-2120.

Delcroix, G.J., Garbayo, E., Sindji, L., Thomas, O., Vanpouille-Box, C., Schiller, P.C., MonteroMenei, C.N., 2011. The therapeutic potential of human multipotent mesenchymal stromal cells combined with pharmacologically active microcarriers transplanted in hemi-parkinsonian rats. Biomaterials 32, 1560-1573.

D'Ippolito, G., Howard, G.A., Roos, B.A., Schiller, P.C., 2006. Isolation and characterization of marrow-isolated adult multilineage inducible (MIAMI) cells. Exp. Hematol. 34, 1608-1610.

Dunnett, S.B., Rosser, A.E., 2011. Clinical translation of cell transplantation in the brain. Curr. Opin. Organ Transplant. 16, 632-639.

Ecker, D., Unrath, A., Kassubek, J., Sabolek, M., 2009. Dopamine agonists and their risk to induce psychotic episodes in Parkinson's disease: a case-control study. BMC Neurol. 9, 23.

Finley, M., Fairman, D., Liu, D., Li, P., Wood, A., Cho, S., 2004. Functional validation of adult hippocampal organotypic cultures as an in vitro model of brain injury. Brain Res. $1001,125-132$.

Freed, W.J., Poltorak, M., Becker, J.B., 1990. Intracerebral adrenal medulla grafts: a review. Exp. Neurol. 110, 139-166.

Froeling, F.E., Marshall, J.F., Kocher, H.M., 2010. Pancreatic cancer organotypic cultures. J. Biotechnol. 148, 16-23.

Gahwiler, B.H., 1981. Organotypic monolayer cultures of nervous tissue. J. Neurosci. Methods 4, 329-342.

Gahwiler, B.H., Capogna, M., Debanne, D., Mckinney, R.A., Thompson, S.M., 1997. Organotypic slice cultures: a technique has come of age. Trends Neurosci. 20, 471-477.

Garbayo, E., Delcroix, G.J.-R., Schiller, P.C., Montero-Menei, C.N., 2011a. Advances in the Combined Use of Adult Cell Therapy and Scaffolds for Brain Tissue Engineering.

Garbayo, E., Raval, A.P., Curtis, K.M., Della-Morte, D., Gomez, L.A., D'Ippolito, G., Reiner, T. Perez-Stable, C., Howard, G.A., Perez-Pinzon, M.A., Montero-Menei, C.N., Schiller, P.C. 2011b. Neuroprotective properties of marrow-isolated adult multilineage-inducible cells in rat hippocampus following global cerebral ischemia are enhanced when complexed to biomimetic microcarriers. J. Neurochem. 119, 972-988.

Gazewood, J.D., Richards, D.R., Clebak, K., 2013. Parkinson disease: an update. Am. Fam. Physician 87, 267-273.

Gross, R.E., Watts, R.L., Hauser, R.A., Bakay, R.A., Reichmann, H., Von Kummer, R., Ondo, W.G., Reissig, E., Eisner, W., Steiner-Schulze, H., Siedentop, H., Fichte, K., Hong, W., Cornfeldt, M., Beebe, K., Sandbrink, R., 2011. Intrastriatal transplantation of microcarrier-bound human retinal pigment epithelial cells versus sham surgery in patients with advanced Parkinson's disease: a double-blind, randomised, controlled trial. Lancet Neurol. 10, 509-519.

Ha, A.D., Fung, V.S., 2012. Huntington's disease. Curr. Opin. Neurol. 25, 491-498.

Hall, A.A., Leonardo, C.C., Collier, L.A., Rowe, D.D., Willing, A.E., Pennypacker, K.R., 2009 Delayed treatments for stroke influence neuronal death in rat organotypic slice cultures subjected to oxygen glucose deprivation. Neuroscience 164, 470-477.

Halliday, G.M., McCann, H., 2010. The progression of pathology in Parkinson's disease. Ann. N. Y. Acad. Sci. 1184, 188-195.

Hauser, R.A., 2009. Levodopa: past, present, and future. Eur. Neurol. 62, 1-8.

Hay, D.G., Sathasivam, K., Tobaben, S., Stahl, B., Marber, M., Mestril, R., Mahal, A., Smith, D.L., Woodman, B., Bates, G.P., 2004. Progressive decrease in chaperone protein levels in a mouse model of Huntington's disease and induction of stress proteins as a therapeutic approach. Hum. Mol. Genet. 13, 1389-1405.

Heppner, F.L., Skutella, T., Hailer, N.P., Haas, D., Nitsch, R., 1998. Activated microglial cells migrate towards sites of excitotoxic neuronal injury inside organotypic hippocampal slice cultures. Eur. J. Neurosci. 10, 3284-3290.

Ho, L.W., Carmichael, J., Wyttenbach, A., Rankin, J., Rubinsztein, D.C., 2001. The molecular biology of Huntington's disease. Psychol. Med. 31, 3-14.

Horn, A.P., Frozza, R.L., Grudzinski, P.B., Gerhardt, D., Hoppe, J.B., Bruno, A.N., Chagastelles P., Nardi, N.B., Lenz, G., Salbego, C., 2009. Conditioned medium from mesenchymal stem cells induces cell death in organotypic cultures of rat hippocampus and aggravates lesion in a model of oxygen and glucose deprivation. Neurosci. Res. 63, 35-41.

Ishihara, M., Mochizuki-Oda, N., Iwatsuki, K., Kishima, H., Iwamoto, Y., Ohnishi, Y., Umegaki, M., Yoshimine, T., 2011. A new three-dimensional axonal outgrowth assay for central nervous system regeneration. J. Neurosci. Methods 198, 181-186.

Jaderstad, J., Jaderstad, L.M., Li, J., Chintawar, S., Salto, C., Pandolfo, M., Ourednik, V., Teng Y.D., Sidman, R.L., Arenas, E., Snyder, E.Y., Herlenius, E., 2010a. Communication via gap junctions underlies early functional and beneficial interactions between grafted neural stem cells and the host. Proc. Natl. Acad. Sci. U. S. A. 107, 5184-5189.

Jaderstad, L.M., Jaderstad, J., Herlenius, E., 2010b. Graft and host interactions following transplantation of neural stem cells to organotypic striatal cultures. Regen. Med. 5, 901-917.

Jaderstad, J., Jaderstad, L.M., Herlenius, E., 2011. Dynamic changes in connexin expression following engraftment of neural stem cells to striatal tissue. Exp. Cell Res. 317, 70-81.

Jaeger, C., Gonzalo Ruiz, A., Llinas, R., 1989. Organotypic slice cultures of dopaminergic neurons of substantia nigra. Brain Res. Bull. 22, 981-991.

Jana, N.R., Tanaka, M., Wang, G., Nukina, N., 2000. Polyglutamine length-dependent interaction of Hsp40 and Hsp70 family chaperones with truncated N-terminal huntingtin: their role in suppression of aggregation and cellular toxicity. Hum. Mol. Genet. 9, 2009-2018.

Jeong, D.K., Taghavi, C.E., Song, K.J., Lee, K.B., Kang, H.W., 2011. Organotypic human spinal cord slice culture as an alternative to direct transplantation of human bone marrow precursor cells for treating spinal cord injury. World Neurosurg. 75, 533-539.

Jung, S., Kim, H.W., Lee, J.H., Kang, S.S., Rhu, H.H., Jeong, Y.I., Yang, S.Y., Chung, H.Y., Bae, C.S., Choi, C., Shin, B.A., Kim, K.K., Ahn, K.Y., 2002. Brain tumor invasion model system using organotypic brain-slice culture as an alternative to in vivo model. J. Cancer Res. Clin. Oncol. 128, 469-476.

Jurga, M., Dainiak, M.B., Sarnowska, A., Jablonska, A., Tripathi, A., Plieva, F.M., Savina, I.N.,

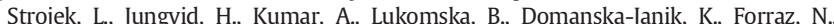
Mcguckin, C.P., 2011. The performance of laminin-containing cryogel scaffolds in neural tissue regeneration. Biomaterials 32, 3423-3434.

Kearns, S.M., Scheffler, B., Goetz, A.K., Lin, D.D., Baker, H.D., Roper, S.N., Mandel, R.J., Steindler, D.A., 2006. A method for a more complete in vitro Parkinson's model: slice culture bioassay for modeling maintenance and repair of the nigrostriatal circuit. J. Neurosci. Methods 157, 1-9.

Kondziolka, D., Wechsler, L., Goldstein, S., Meltzer, C., Thulborn, K.R., Gebel, J., Jannetta, P. Decesare, S., Elder, E.M., Mcgrogan, M., Reitman, M.A., Bynum, L., 2000. Transplantation of cultured human neuronal cells for patients with stroke. Neurology 55, 565-569.

Kress, G.J., Reynolds, I.J., 2005. Dopaminergic neurotoxins require excitotoxic stimulation in organotypic cultures. Neurobiol. Dis. 20, 639-645.

Lees, A.J., Hardy, J., Revesz, T., 2009. Parkinson's disease. Lancet 373, 2055-2066.

Lévesque, M.F., Toomas, N., Rezak, M., 2009. Therapeutic microinjection of autologous adult human neural stem cells and differentiated neurons for Parkinson's disease: five-year post-operative outcome. Open Stem Cell J. 1, 20-29.

Li, W.Y., Choi, Y.J., Lee, P.H., Huh, K., Kang, Y.M., Kim, H.S., Ahn, Y.H., Lee, G., Bang, O.Y., 2008. Mesenchymal stem cells for ischemic stroke: changes in effects after ex vivo culturing. Cell Transplant. 17, 1045-1059.

Lindvall, O., 2013. Developing dopaminergic cell therapy for Parkinson's disease-give up or move forward? Mov. Disord. 28 (3), 268-273.

Lindvall, O., Kokaia, Z., Martinez-Serrano, A., 2004. Stem cell therapy for human neurodegenerative disorders-how to make it work. Nat. Med. 10, S42-S50 (Suppl.).

Liu, J., Huang, H.Y., 2007. How to improve the survival of the fetal ventral mesencephalic cell transplanted in Parkinson's disease? Neurosci. Bull. 23, 377-382.

Lloyd-Jones, D., Adams, R.J., Brown, T.M., Carnethon, M., Dai, S., De Simone, G., Ferguson, T.B., Ford, E., Furie, K., Gillespie, C., Go, A., Greenlund, K., Haase, N., Hailpern, S., Ho, P.M., Howard, V., Kissela, B., Kittner, S., Lackland, D., Lisabeth, L., Marelli, A. McDermott, M.M., Meigs, J., Mozaffarian, D., Mussolino, M., Nichol, G., Roger, V.L., Rosamond, W., Sacco, R., Sorlie, P., Thom, T., Wasserthiel-Smoller, S., Wong, N.D. Wylie-Rosett, J., 2010. Heart disease and stroke statistics-2010 update: a report from the American Heart Association. Circulation 121, e46-e215.

Loffredo Sampaolo, C., 1956. Chick embryo heart in organotypic culture. Boll. Soc. Ital. Biol. Sper. 32, 1580-1582.

Lopez-Barneo, J., Pardal, R., Ortega-Saenz, P., Duran, R., Villadiego, J., Toledo-Aral, J.J., 2009. The neurogenic niche in the carotid body and its applicability to antiparkinsonian cell therapy. J. Neural Transm. 116, 975-982. 
Lye, M., Jakobs, T., Masland, R., Koizumi, A., 2007. Organotypic culture of adult rabbit retina. J. Vis. Exp. 190.

Matyja, E., 1986. Morphologic evidence of a primary response of gila to kainic acid administration into the rat neostriatum; studied in vivo and in vitro. Exp. Neurol. 92, 609-623.

Meerovitch, E., 1961. Growth of Entamoeba invadens in organotypic cultures of embryonic chick intestine. Can. J. Microbiol. 7, 685-695.

Mendez, I., Sanchez-Pernaute, R., Cooper, O., Vinuela, A., Ferrari, D., Bjorklund, L., Dagher, A., Isacson, O., 2005. Cell type analysis of functional fetal dopamine cell suspension transplants in the striatum and substantia nigra of patients with Parkinson's disease. Brain 128, 1498-1510.

Meng, X., Seton, H.C., Lu Le, T., Prior, I.A., Thanh, N.T., Song, B., 2011. Magnetic CoPt nanoparticles as MRI contrast agent for transplanted neural stem cells detection. Nanoscale 3, 977-984.

Metzger, M., Bareiss, P.M., Nikolov, I., Skutella, T., Just, L., 2007. Three-dimensional slice cultures from murine fetal gut for investigations of the enteric nervous system. Dev. Dyn. 236, 128-133.

Minguez-Castellanos, A., Escamilla-Sevilla, F., Hotton, G.R., Toledo-Aral, J.J., OrtegaMoreno, A., Mendez-Ferrer, S., Martin-Linares, J.M., Katati, M.J., Mir, P., Villadiego, J., Meersmans, M., Perez-Garcia, M., Brooks, D.J., Arjona, V., Lopez-Barneo, J., 2007. Carotid body autotransplantation in Parkinson disease: a clinical and positron emission tomography study. J. Neurol. Neurosurg. Psychiatry 78, 825-831.

Modo, M., Stroemer, R.P., Tang, E., Patel, S., Hodges, H., 2002. Effects of implantation site of stem cell grafts on behavioral recovery from stroke damage. Stroke 33, 2270-2278.

Mori, T., Iwai, M., Harada, Y., Tanaka, S., Muramatsu, A., Okanoue, T., Kashima, K., Fushiki, S., 1999. Parenchymal cells proliferate and differentiate in an organotypic slice culture of the neonatal liver. Anat. Embryol. (Berl) 199, 319-327.

Murphy, R.C., Messer, A., 2001. Gene transfer methods for CNS organotypic cultures: comparison of three nonviral methods. Mol. Ther. 3, 113-121.

Murphy, R.C., Messer, A., 2004. A single-chain Fv intrabody provides functional protection against the effects of mutant protein in an organotypic slice culture model of Huntington's disease. Brain Res. Mol. Brain Res. 121, 141-145.

Nakagami, Y., Saito, H., Matsuki, N., 1997. Basic fibroblast growth factor and brain-derived neurotrophic factor promote survival and neuronal circuit formation in organotypic hippocampal culture. Jpn. J. Pharmacol. 75, 319-326.

Nikkhah, G., Rosenthal, C., Falkenstein, G., Roedter, A., Papazoglou, A., Brandis, A., 2009. Microtransplantation of dopaminergic cell suspensions: further characterization and optimization of grafting parameters. Cell Transplant. 18, 119-133.

Noraberg, J., Poulsen, F.R., Blaabjerg, M., Kristensen, B.W., Bonde, C., Montero, M., Meyer, M., Gramsbergen, J.B., Zimmer, J., 2005. Organotypic hippocampal slice cultures for studies of brain damage, neuroprotection and neurorepair. Curr. Drug Targets CNS Neurol. Disord. 4, 435-452.

Olanow, C.W., Goetz, C.G., Kordower, J.H., Stoessl, A.J., Sossi, V., Brin, M.F., Shannon, K.M. Nauert, G.M., Perl, D.P., Godbold, J., Freeman, T.B., 2003. A double-blind controlled trial of bilateral fetal nigral transplantation in Parkinson's disease. Ann. Neurol. 54 403-414.

Ostergaard, K., Schou, J.P., Zimmer, J., 1990. Rat ventral mesencephalon grown as organotypic slice cultures and co-cultured with striatum, hippocampus, and cerebellum. Exp. Brain Res. 82, 547-565.

Park, K.I., Hack, M.A., Ourednik, J., Yandava, B., Flax, J.D., Stieg, P.E., Gullans, S. Jensen, F.E., Sidman, R.L., Ourednik, V., Snyder, E.Y., 2006. Acute injury directs the migration, proliferation, and differentiation of solid organ stem cells: evidence from the effect of hypoxia-ischemia in the CNS on clonal "reporter" neural stem cells. Exp. Neurol. 199, 156-178.

Perese, D.A., Ulman, J., Viola, J., Ewing, S.E., Bankiewicz, K.S., 1989. A 6-hydroxydopamineinduced selective parkinsonian rat model. Brain Res. 494, 285-293.

Perier, C., Bove, J., Vila, M., Przedborski, S., 2003. The rotenone model of Parkinson's disease. Trends Neurosci. 26, 345-346.

Plenz, D., Aertsen, A., 1996a. Neural dynamics in cortex-striatum co-cultures-II Spatiotemporal characteristics of neuronal activity. Neuroscience 70, 893-924.

Plenz, D., Aertsen, A., 1996b. Neural dynamics in cortex-striatum co-cultures-I. anatomy and electrophysiology of neuronal cell types. Neuroscience 70, 861-891.

Plenz, D., Kitai, S.T., 1996. Organotypic cortex-striatum-mesencephalon cultures: the nigrostriatal pathway. Neurosci. Lett. 209, 177-180.

Pozzo Miller, L.D., Mahanty, N.K., Connor, J.A., Landis, D.M., 1994. Spontaneous pyramida cell death in organotypic slice cultures from rat hippocampus is prevented by glutamate receptor antagonists. Neuroscience 63, 471-487.

Raval, A.P., Dave, K.R., Mochly-Rosen, D., Sick, T.J., Perez-Pinzon, M.A., 2003. Epsilon PKC is required for the induction of tolerance by ischemic and NMDA-mediated preconditioning in the organotypic hippocampal slice. J. Neurosci. 23, 384-391.

Reinhart, P.H., Kaltenbach, L.S., Essrich, C., Dunn, D.E., Eudailey, J.A., Demarco, C.T., Turmel, G.J., Whaley, J.C., Wood, A., Cho, S., Lo, D.C., 2011. Identification of anti-inflammatory targets for Huntington's disease using a brain slice-based screening assay. Neurobiol. Dis. 43, 248-256.

Sarnowska, A., Braun, H., Sauerzweig, S., Reymann, K.G., 2009a. The neuroprotective effect of bone marrow stem cells is not dependent on direct cell contact with hypoxic injured tissue. Exp. Neurol. 215, 317-327.

Sarnowska, A., Jurga, M., Buzanska, L., Filipkowski, R.K., Duniec, K., Domanska-Janik, K, 2009b. Bilateral interaction between cord blood-derived human neural stem cells and organotypic rat hippocampal culture. Stem Cells Dev. 18, 1191-1200.

Savas, A., Warnke, P.C., Ginap, T., Feuerstein, T.J., Ostertag, C.B., 2001. The effects of continuous and single-dose radiation on choline uptake in organotypic tissue slice cultures of rabbit hippocampus. Neurol. Res. 23, 669-675.

Smith, D.L., Bates, G.P., 2004. Monitoring aggregate formation in organotypic slice cultures from transgenic mice. Methods Mol. Biol. 277, 161-171.
Smith, D.L., Portier, R., Woodman, B., Hockly, E., Mahal, A., Klunk, W.E., Li, X.J., Wanker, E., Murray, K.D., Bates, G.P., 2001. Inhibition of polyglutamine aggregation in R6/2 HD brain slices-complex dose-response profiles. Neurobiol. Dis. 8, 1017-1026.

Sorensen, J.C., Ostergaard, K., Zimmer, J., 1994. Grafting of dopaminergic ventral mesencephalic slice cultures to the striatum of adult rats. Exp. Neurol. 127, 199-206.

Stahl, K., Skare, O., Torp, R., 2009. Organotypic cultures as a model of Parkinson s disease. A twist to an old model. Scientific World Journal 9, 811-821.

Stoppini, L., Buchs, P.A., Muller, D., 1991. A simple method for organotypic cultures of nervous tissue. J. Neurosci. Methods 37, 173-182.

Storgaard, J., Kornblit, B.T., Zimmer, J., Gramsbergen, J.B., 2000. 3-Nitropropionic acid neurotoxicity in organotypic striatal and corticostriatal slice cultures is dependent on glucose and glutamate. Exp. Neurol. 164, 227-235.

Stover, N.P., Bakay, R.A., Subramanian, T., Raiser, C.D., Cornfeldt, M.L., Schweikert, A.W., Allen, R.C., Watts, R.L., 2005. Intrastriatal implantation of human retinal pigment epithelial cells attached to microcarriers in advanced Parkinson disease. Arch. Neurol. 62, 1833-1837.

Su, T., Paradiso, B., Long, Y.S., Liao, W.P., Simonato, M., 2011. Evaluation of cell damage in organotypic hippocampal slice culture from adult mouse: a potential model system to study neuroprotection. Brain Res. 1385, 68-76.

Suarez-Monteagudo, C., Hernandez-Ramirez, P., Alvarez-Gonzalez, L., Garcia-Maeso, I., De La Cuetara-Bernal, K., Castillo-Diaz, L., Bringas-Vega, M.L., Martinez-Aching, G., Morales-Chacon, L.M., Baez-Martin, M.M., Sanchez-Catasus, C., Carballo-Barreda, M., Rodriguez-Rojas, R., Gomez-Fernandez, L., Alberti-Amador, E., Macias-Abraham, C., Balea, E.D., Rosales, L.C., Del Valle Perez, L., Ferrer, B.B., Gonzalez, R.M., Bergado, J.A., 2009. Autologous bone marrow stem cell neurotransplantation in stroke patients. An open study. Restor. Neurol. Neurosci. 27, 151-161.

Subramanian, A., Krishnan, U.M., Sethuraman, S., 2009. Development of biomaterial scaffold for nerve tissue engineering: Biomaterial mediated neural regeneration. J. Biomed. Sci. 16, 108

Sundstrom, L., Morrison, B., Bradley III, M., Pringle, A., 2005. Organotypic cultures as tools for functional screening in the CNS. Drug Discov. Today 10, 993-1000.

Tanvig, M., Blaabjerg, M., Andersen, R.K., Villa, A., Rosager, A.M., Poulsen, F.R., MartinezSerrano, A., Zimmer, J., Meyer, M., 2009. A brain slice culture model for studies of endogenous and exogenous precursor cell migration in the rostral migratory stream. Brain Res. 1295, 1-12.

Tarlov, N., Nien, Y.L., Zaidat, O.O., Nguyen, T.N., 2012. Periprocedural management of acute ischemic stroke intervention. Neurology 79, S182-S191.

Tatard, V.M., Venier-Julienne, M.C., Benoit, J.P., Menei, P., Montero-Menei, C.N., 2004. In vivo evaluation of pharmacologically active microcarriers releasing nerve growth factor and conveying PC12 cells. Cell Transplant. 13, 573-583.

Tatard, V.M., Venier-Julienne, M.C., Saulnier, P., Prechter, E., Benoit, J.P., Menei, P., Montero-Menei, C.N., 2005. Pharmacologically active microcarriers: a tool for cell therapy. Biomaterials 26, 3727-3737.

Tatard, V.M., D'Ippolito, G., Diabira, S., Valeyev, A., Hackman, J., McCarthy, M., Bouckenooghe, T., Menei, P., Montero-Menei, C.N., Schiller, P.C., 2007a. Neurotrophin-directed differentiation of human adult marrow stromal cells to dopaminergic-like neurons. Bone 40 , 360-373.

Tatard, V.M., Sindji, L., Branton, J.G., Aubert-Pouessel, A., Colleau, J., Benoit, J.P., Montero-Menei, C.N., 2007b. Pharmacologically active microcarriers releasing glial cell line-derived neurotrophic factor: survival and differentiation of embryonic dopaminergic neurons after grafting in hemiparkinsonian rats. Biomaterials 28, 1978-1988.

Testa, C.M., Sherer, T.B., Greenamyre, J.T., 2005. Rotenone induces oxidative stress and dopaminergic neuron damage in organotypic substantia nigra cultures. Brain Res. Mol. Brain Res. 134, 109-118.

Tomaskovic-Crook, E., Crook, J.M., 2011. Human embryonic stem cell therapies for neurodegenerative diseases. CNS Neurol. Disord. Drug Targets 10, 440-448.

Tonnesen, J., Parish, C.L., Sorensen, A.T., Andersson, A., Lundberg, C., Deisseroth, K., Arenas, E., Lindvall, O., Kokaia, M., 2011. Functional integration of grafted neural stem cellderived dopaminergic neurons monitored by optogenetics in an in vitro Parkinson model. PLoS One 6, e17560.

Turner, C.P., Connell, J., Blackstone, K., Ringler, S.L., 2007. Loss of calcium and increased apoptosis within the same neuron. Brain Res. 1128, 50-60.

Ullrich, C., Daschil, N., Humpel, C., 2011. Organotypic vibrosections: novel whole sagittal brain cultures. J. Neurosci. Methods 201, 131-141.

Varley, C.L., Southgate, J., 2011. Organotypic and 3D reconstructed cultures of the human bladder and urinary tract. Methods Mol. Biol. 695, 197-211.

Venkataramana, N.K., Kumar, S.K., Balaraju, S., Radhakrishnan, R.C., Bansal, A., Dixit, A., Rao, D.K., Das, M., Jan, M., Gupta, P.K., Totey, S.M., 2010. Open-labeled study of unilateral autologous bone-marrow-derived mesenchymal stem cell transplantation in Parkinson's disease. Transl. Res. 155, 62-70.

Volles, M.J., Lansbury Jr., P.T., 2003. Zeroing in on the pathogenic form of alpha-synuclein and its mechanism of neurotoxicity in Parkinson's disease. Biochemistry 42, $7871-7878$

Walker, F.O., 2007. Huntington's disease. Lancet 369, 218-228.

Whetsell Jr., W.O., Schwarcz, R., 1989. Prolonged exposure to submicromolar concentrations of quinolinic acid causes excitotoxic damage in organotypic cultures of rat corticostriatal system. Neurosci. Lett. 97, 271-275.

Wijeyekoon, R., Barker, R.A., 2011. The current status of neural grafting in the treatment of Huntington's disease. A review. Front. Integr. Neurosci. 5, 78

Williams, C.A., Lavik, E.B., 2009. Engineering the CNS stem cell microenvironment. Regen. Med. 4, 865-877.

Xu, G.P., Dave, K.R., Vivero, R., Schmidt-Kastner, R., Sick, T.J., Perez-Pinzon, M.A., 2002. Improvement in neuronal survival after ischemic preconditioning in hippocampal slice cultures. Brain Res. 952, 153-158. 
Xu, G., Perez-Pinzon, M.A., Sick, T.J., 2003. Mitochondrial complex I inhibition produces selective damage to hippocampal subfield CA1 in organotypic slice cultures. Neurotox. Res. 5, 529-538.

Zhong, C., Qin, Z., Zhong, C.J., Wang, Y., Shen, X.Y., 2003. Neuroprotective effects of bone marrow stromal cells on rat organotypic hippocampal slice culture model of cerebral ischemia. Neurosci. Lett. 342, 93-96.
Ziemka-Nalecz, M., Stanaszek, L., Zalewska, T., 2013. Oxygen-glucose deprivation promotes gliogenesis and microglia activation in organotypic hippocampal slice culture: involvement of metalloproteinases. Acta Neurobiol. Exp. (Wars) 73, 130-142.

Zurich, M.G., Monnet-Tschudi, F., 2009. Contribution of in vitro neurotoxicology studies to the elucidation of neurodegenerative processes. Brain Res. Bull. 80, 211-216. 